\title{
Complementary therapies for supportive cancer care
}

\author{
Edzard Ernst
}

Received: 1 October 2009 / Accepted: 16 August 2010/Published online: 28 August 2010

(C) Springer-Verlag 2010

"Randomised controlled trials of specific therapies...rarely demonstrate any benefit in terms of quality of life" [1]. This is a statement from a recent article in this journal dealing with complementary therapies for supportive cancer care. It made me ponder. Is this really true? I don't think so!

Anyone who cares to look up the trial data will find hundreds of studies - far too many to review here in detail. So let's just look up (some of) the systematic reviews which are available, many from this journal. At least some encouraging evidence has emerged from systematic reviews of the following treatments: (for a fuller discussion of the treatments involved, the reader is referred elsewhere [2]).

- Acupressure for chemotherapy-induced nausea [3, 4]

- Acupuncture for cancer pain [5]

- Acupuncture for hot flushes in men with prostate cancer [6]

- Acupuncture for hot flushes in women with breast cancer [7]

- Aromatherapy for improving well-being of patients with cancer [8]

- Chinese herbal medicine for improving quality of life [9]

- Co-enzyme Q10 for reducing the toxicity of cancer drugs [10]

- Exercise for fatigue and nausea [11, 12]

- Exercise for improving quality of life [13]

- Guided imagery for reducing anxiety [14]

- Hypnosis for reducing cancer pain [15]

\section{E. Ernst $(\bowtie)$}

Complementary Medicine, Peninsula Medical School,

University of Exeter,

25 Victoria Park Road,

Exeter EX2 4NT, UK

e-mail: Edzard.Ernst@pms.ac.uk
- Massage for a wide range of symptoms and for improving quality of life [16]

- Music therapy for improving quality of life [17]

- Qigong for improving quality of life [18]

- Tai chi for improving psychological symptoms [19]

I am, of course, not claiming that the evidence for all the listed treatments is compelling, but I insist that there are at least some encouraging trial data. In fact, some of the approaches, e.g. acupuncture in the treatment of nausea or exercise in the treatment of asthenia, are today generally accepted in routine supportive care. Other treatments, e.g. Co-enzyme Q10 or Qigong, are clearly not well enough researched and necessitate confirmatory studies.

I believe, we need to build on this evidence. We need more clinical trials and we need better clinical trials. By "better", I mean trials that successfully minimise bias. Certain study designs that are popular for pragmatic trials have zero chance of generating a negative result, even if the tested intervention is devoid of any specific therapeutic effects [20]. Therefore such investigations have the potential to mislead us.

The challenges for future research are numerous and complex. On the one hand, we need evidence that applies to "real life" situations in supportive care. On the other hand, we should thrive to establish cause and effect with reasonable certainty. Sailing between the "Scylla and Charybdis:" will not be easy, and a discussion about how this might be best achieved is clearly beyond the scope of this short comment, particularly as this area is the subject of much controversy within CAM research [21].

A likely strategy could be to employ a mixed method approach of observational studies, pragmatic and fastidious trials and, at the same time, be cognisant of the limitation of each of these approaches. 
If we follow this path, we might eventually arrive at a point where we are able to tell with confidence that this treatment is useful while that one is not, and to determine that one therapy is better than another for achieving a specific therapeutic goal. Ignoring or downplaying the importance of clinical trials [1] in sorting out the wheat from the chaff will not help anyoneleast of all the cancer patient.

\section{Conflict of interest None.}

\section{External funding None.}

\section{References}

1. Seers HE, Gale N, Paterson C, Cooke HJ, Tuffrey V, Polley MJ (2009) Individualised and complex experiences of integrative cancer support care: combining qualitative and quantitative data. Support Care Cancer 17(9):1159-1167

2. Ernst E, Pittler MH, Wider B, Boddy K (2006) The Desktop Guide to Complementary and Alternative Medicine, 2nd edn. Elsevier Mosby, Edinburgh

3. Klein J, Griffiths P (2004) Acupressure for nausea and vomiting in cancer patients receiving chemotherapy. Br J Community Nurs 9(9):383-388

4. Vickers AJ (1996) Can acupuncture have specific effects on health? A systematic review of acupuncture anti-emesis trials. J Roy Soc Med 89(6):303-311

5. Lee H, Schmidt K, Ernst E (2005) Acupuncture for the relief of cancer-related pain - a systematic review. Eur J Pain 9(4):437-444

6. Lee MS, Kim KH, Shin BC, Choi SM, Ernst E (2009) Acupuncture for treating hot flushes in men with prostate cancer: a systematic review. Support Care Cancer 17(7):763-770

7. Lee MS, Kim KH, Choi SM, Ernst E (2009) Acupuncture for treating hot flashes in breast cancer patients: a systematic review. Breast Cancer Res Treat 115(3):497-503

8. Fellowes D, Barnes K, Wilkinson S (2004) Aromatherapy and massage for symptom relief in patients with cancer. Cochrane
Database Syst Rev. doi:10.1002/14651858.CD002287, Issue 3, Art No. CD002287

9. Molassiotis A, Potrata B, Cheng KK (2009) A systematic review of the effectiveness of Chinese herbal medication in symptom management and improvement of quality of life in adult cancer patients. Complement Ther Med 17(2):92-120

10. Roffe L, Schmidt K, Ernst E (2004) Efficacy of coenzyme Q10 for improved tolerability of cancer treatments: a systematic review. J Clin Oncol 22(21):4418-4424

11. Dimeo F (2004) Welche Rolle spielt körperliche Aktivität in der Prävention, Therapie und Rehabilitation von neoplastischen Erkrankungen? Deutsche Zeitschr Sportmed 55:177182

12. Cramp F, Daniel J (2008) Exercise for the management of cancerrelated fatigue in adults. Cochrane Database Syst Rev. doi:10.1002/14651858.CD006145.pub2, Issue 2, Art. No.: CD006145

13. Conn VS, Hafdahl AR, Porock DC, McDaniel R, Nielsen PJ (2006) A meta-analysis of exercise interventions among people treated for cancer. Support Care Cancer 14(7):699-712

14. Roffe L, Schmidt K, Ernst E (2005) A systematic review of guided imagery as an adjuvant cancer therapy. Psychooncol 14 (8):607-617

15. Bardia A, Barton DL, Prokop LJ, Bauer BA, Moynihan TJ (2006) Efficacy of complementary and alternative medicine therapies in relieving cancer pain: a systematic review. J Clin Oncol 24 (34):5457-5464

16. Ernst E (2009) Massage therapy for cancer palliation and supportive care: a systematic review of randomised clinical trials. Support Care Cancer 17(4):333-337

17. Dileo C, Bradt J (2008) Music therapy for end-of-life care. (Protocol). Cochrane Database of Syst Rev. doi:10.1002/ 14651858.CD007169, Issue 2, Art. No.: CD007169

18. Lee MS, Chen KW, Sancier KM, Ernst E (2007) Qigong for cancer treatment: a systematic review of controlled clinical trials. Acta Oncol 46(6):717-722

19. Lee MS, Pittler MH, Ernst E (2007) Is Tai Chi an effective adjunct in cancer care? A systematic review of controlled clinical trials. Support Care Cancer 15(6):597-601

20. Ernst E, Lee MS (2008) A trial design that generates only "positive" results. J Postgrad Med 54(3):214-216

21. Witt CM (2009) Efficacy, effectiveness, pragmatic trials-guidance on terminology and the advantages of pragmatic trials. Forsch Komplementmed 16(5):292-294 